\title{
Dispersal of mahogany seeds and seedlings (Swietenia macrophylla) in open ombrophilous forest with palm trees from southeastern Pará, Brazil
}

We performed a study of dispersal of mahogany seeds and seedlings (Swietenia macrophylla King, Meliaceae) in open ombrophilous forest with palm trees from southeastern Pará. For this study, we placed four transects of $2 \times 50 \mathrm{~m}$, each subdivided in 25 blocs of $2 \times 2 \mathrm{~m}$, in the directions N, S, E, W of four mahogany matrices. We found that: seeds dispersed according to the direction of prevailing winds that favored higher density and dispersal distance in the $\mathrm{W}$ - $\mathrm{N}$ direction; the intact seeds have reached greater dispersal distances than the aborted ones and can be dispersed beyond the matrix tree $50 \mathrm{~m}$ distance in the west direction; the greatest abundance of seeds and seedlings was found between 10 and $20 \mathrm{~m}$ distance from the matrices; seedling density was considered low, however, it increases from the east to west direction of the matrices, and can be found beyond the $50 \mathrm{~m}$ distance in the $\mathrm{N}$ and $\mathrm{W}$ directions; the size of mahogany seeds is more important in determining the weight than width, which is a more conservative variable; the recruitment and growth of seedlings seem to be associated with clearings - where the highest heights were observed - which are quite disturbed sites with a higher incidence of light and other environmental seasonality. The information provide here may contribute to enhance the management actions for the use of the species included in the Appendix II of CITES.

\section{Dispersão de sementes e mudas de mogno (Swietenia macrophylla) em floresta ombrófila aberta com palmeiras do sudeste do Pará, Brasil}

Foi realizado um estudo de dispersão de sementes e mudas de mogno (Swietenia macrophylla King, Meliaceae) em floresta ombrófila aberta com palmeiras do sudeste do Pará. Para este estudo, foram colocados quatro transectos de $2 \times 50 \mathrm{~m}$, cada um subdividido em 25 blocos de $2 \times 2 \mathrm{~m}$, nas direções N, S, E, W de quatro matrizes de mogno. Descobrimos que: sementes dispersas de acordo com a direção dos ventos dominantes que favorecem maior densidade e distância de dispersão na direção $\mathrm{W}$ - N; as sementes intactas alcançaram maiores distâncias de dispersão que as abortadas e podem ser dispersadas para além da árvore matriz a $50 \mathrm{~m}$ de distância na direção oeste; a maior abundância de sementes e plântulas foi encontrada entre 10 e 20 m de distância das matrizes; a densidade de plântulas foi considerada baixa, no entanto, aumenta da direção leste para oeste das matrizes, e pode ser encontrada além da distância de $50 \mathrm{~m}$ nas direções $\mathrm{N}$ e W; o tamanho das sementes de mogno é mais importante na determinação do peso que a largura, que é uma variável mais conservadora; o recrutamento e o crescimento de plântulas parecem estar associados a clareiras - onde foram observadas as maiores altitudes - locais bastante perturbados com maior incidência de luz e outras sazonalidades ambientais. As informações fornecidas aqui podem contribuir para aprimorar as ações de manejo para o uso das espécies incluídas no Anexo II da CITES.

Keywords: Anemocoria; Gestão; Árvore comercial; Amazônia.

Topic: Conservação da Biodiversidade

Reviewed anonymously in the process of blind peer
Received: 07/07/2018

Approved: 17/09/2018
Diego Guimarães de Sousa

Universidade Estadual de Goiás, Brasil

http://lattes.cnpq.br/2281840334742279

http://orcid.org/0000-0002-9456-1639

diegoagro97@hotmail.com

Hélida Ferreira da Cunha (iD

Universidade Estadual de Goiás, Brasil

http://lattes.cnpq.br/4200078844171756

http://orcid.org/0000-0002-2821-3986

cunhahf@ueg.br
8

DOI: 10.6008/CBPC2318-2881.2018.002.0001
Referencing this:

SOUSA, D. G.; CUNHA, H. F.. Dispersal of mahogany seeds and seedlings (Swietenia macrophylla) in open ombrophilous forest with palm trees from southeastern Pará, Brazil. Nature and Conservation v.11, n.2, p.1-12, 2018. DOI: http://doi.org/10.6008/CBPC23182881.2018.002.0001 


\section{INTRODUCTION}

Swietenia macrophylla King (Meliaceae), also known as mahogany, is an anemochoric species (Lamb 1966). Such species seem to have evolved independently, within several families of woody plants (Janzen 1980 ) and are capable to disperse seeds to considerable distances from the parent plants, escaping from high predation near the matrix (NASCIMENTO et al., 2002).

In Mexico and Bolivia, the recruitment of mahogany seedlings has been associated to large-scale disturbances, such as hurricanes, forest fires, floods and deforestation for agriculture (SNOOK, 1993; GULLISON et al., 1996). However, in southeastern Pará, recruitment seems to be associated with clearings caused by the natural fall of trees and disturbances in areas of abandoned log yards (GROGAN, 2001).

The species is among the world's highest timber prices (GROGAN et al., 2002), and is at the forefront of sustainable forest management viability debates (RICE et al., 1997; FREE et al., 2014). The high commercial importance of mahogany and its ecological vulnerability have been the subject of intense controversy over how to guarantee the conservation and sustainable use of this species (GROGAN et al., 2002). It is currently included in Appendix II of CITES (the Convention on International Trade in Endangered Species), which requires each exporting country to define sustainable levels of exploitation of the species and to grant export licenses (RODAN et al., 2003).

In this context: Grogan et al. (2002) and Snook et al. (2003) present recommendations for mahogany management and forestry, as well as options for the species conservation; Gutiérrez-Granado (2011) described the effects of natural and anthropogenic disturbances on mahogany regeneration and its implications for the management of tropical forests; Grogan et al. (2014), Free et al. (2014) and Grogan et al. (2013) analyzed the implications of population and phenological dynamics for the sustainable management of the species for logging purposes.

The present study aimed to characterize the seeds and seedlings dispersal of S. macrophylla in an open ombrophilous forest with palm trees in southeastern Pará. Among the main questions, we sought to know: whether the direction of prevailing winds influences the abundance, spatial distribution and dispersal distance of seeds and seedlings; whether the seed viability state influences its dispersion distance; (3) if seedlings located in clearing environments are larger in height than those located in the understory of the forest. The results obtained have a direct implication for management programs that use seed dispersal methods to establish natural regeneration as a basis for the maintenance of the population structure of the species.

\section{MATERIALS AND METHODS}

\section{Study area}

This study was carried out in a forest fragment of approximately 2700 ha comprising the legal reserves of the São Francisco and Sombra da Mata farms, in the municipality of Palestina do Pará, in the southeastern State of Pará. The area is located at $05^{\circ} 59^{\prime} 48^{\prime \prime} \mathrm{S}$ e $48^{\circ} 23^{\prime} 50^{\prime \prime} \mathrm{W}$, with average altitude of 118 $m$ and its phytophysiognomy is submontane open ombrophilous forest with palm trees (IBGE, 2012). The 
local soil is of the group yellow latosol of clayey silt texture. The climate of the area is Aw (Köppen classification), characterized as a humid tropical climate, with dry winter. The average annual temperature varies from $26^{\circ}$ to $27^{\circ} \mathrm{C}$, with maximum of $33^{\circ} \mathrm{C}$ and minimum of $22^{\circ} \mathrm{C}$. The rainy season comprises the months of November to April (from 75 to 100 days with rain), with annual precipitation ranging from 1500 to 1750 mm (UNICEF, 1996). During the dry season there is predominance of east winds (GROGAN et al., 2002).

\section{Sampling}

The methodology of this study was based on Nascimento et al. (2002) and Aragão et al. (1997), with some modifications. In September 2004, we randomly selected in a systematic way four adult trees of $S$. macrophylla and in seed dispersal process $(50 \mathrm{~cm}<\mathrm{DBH}$ - diameter at breast height, measured at $1.3 \mathrm{~m}$ from the soil $-\leq 81 \mathrm{~cm}$ ), with a minimum distance of $100 \mathrm{~m}$ between them. For each tree, we measured: height, DBH and tree crown radius (in the North $-\mathrm{N}$, South $-\mathrm{S}$, East $-\mathrm{E}$, West - W directions). Four transects of $2 \times 50 \mathrm{~m}$ were constructed as sample units from the trunk of these trees in the N, S, E, W directions. Each transect was divided into 25 blocs of $2 \times 2 \mathrm{~m}\left(4 \mathrm{~m}^{2}\right)$ totaling $100 \mathrm{~m}^{2}$ and $400 \mathrm{~m}^{2}$ per matrix (figure 1 ).

In each block the seeds were counted and their respective survival states (intact, aborted, predated by insect, rodent or infested by fungus) were counted. Two seeds were sampled per bloc, when the total number of seeds in the block was greater than two (blocks containing two seeds, only one was sample, and in blocks containing only one seed, the sample was not performed), for measurements of length, width and weight, with the exosperm removed. The seeds were sample within and between matrices, and measured in length and width, through a caliper.

Subsequently, they were weighed using a precision analytical balance $(0.01 \mathrm{mg})$. The census of all seedlings (here considered as individuals with a height of less than $1 \mathrm{~m}$ ) was also carried out in each block, at the various distances proposed $(2,4,6,8, \ldots, 50 \mathrm{~m}$ mother plant). Their respective total heights were measured and the type of environment where each one was located (whether in understory or clearing) was recorded.

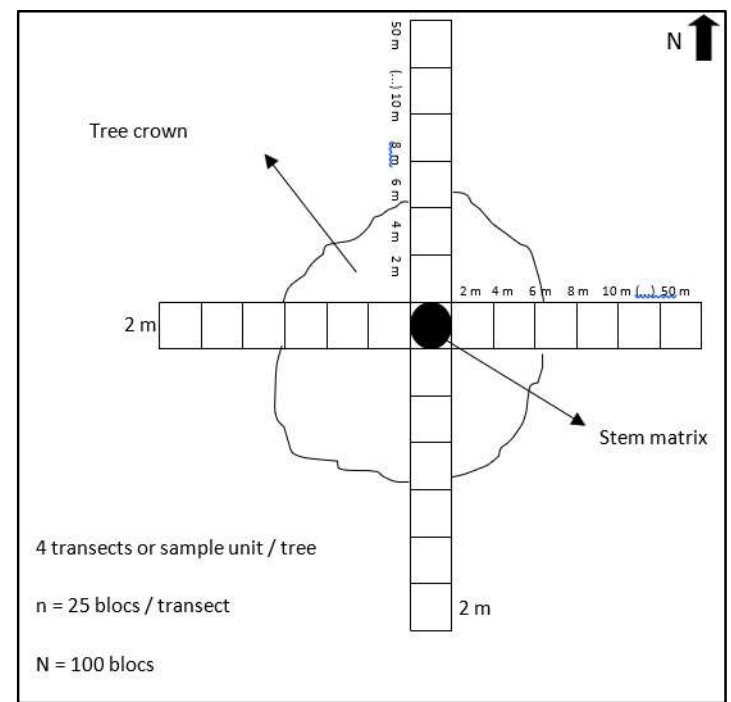

Figure 1: Representation of the transects used for seed and seedlings samplings of Swietenia macrophylla King, in southeastern Pará. 


\section{Analyses}

We performed Analysis of variance (one-way ANOVA) and Tukey's HSD multiple comparison test $(\alpha=0.05)$, to detect significant differences in the mean: of the density and spatial distance of seeds and seedlings located in different transects; of the dispersal distance of seeds with different survival states; of the seedlings' height regarding their parental distance in relation to the parent trees. We used the Pearson correlation coefficient $(r)(\alpha=0.05)$, to verify if there is a relation between the size of canopy radius of the matrices, in $\mathrm{N}, \mathrm{S}, \mathrm{E}, \mathrm{W}$ directions and the number of dispersed seeds in each matrix.

The Student's t-test was used to verify if there is a difference in the average height of seedlings in clearing and understory forest environments. For the seeds, we calculated the arithmetic mean, the standard deviation and the coefficient of variation of their measurements to detect any pattern of morphological variation. Statistical tests were performed using the "vegan" package (OKSANEN et al., 2016) in the $R$ software (RCT, 2016).

\section{THEORETICAL DISCUSSION}

\section{Seeds and seedlings density}

The four S. macrophylla matrices showed mean crown radius of $7.73 \pm 2.32 \mathrm{~m}$, mean height of 22.50 $\pm 5 \mathrm{~m}$ and mean DBH of $69.48 \pm 12.21 \mathrm{~cm}$. A total of 346 seeds and 53 seedlings were sampled in 400 blocks, with a density of 0.22 seeds $\mathrm{m}^{-2}$ and 0.033 seedlings $\mathrm{m}^{-2}$, respectively (table 1 ). The mean number of seedlings per matrix was $10.1 \pm 6.87$ ind matrix $^{-1}$.

The mean seed density varied significantly among the $\left(F_{(3.396)}=12.339 ; p<0.001\right)$. The transects sampled in the west direction had a higher number of seeds inventoried, with about $60 \%$ of the total, and a higher average density of seeds per unit area $\left(0.5\right.$ seeds $\left.\mathrm{m}^{-2}\right)$. Northern transects accounted for $30 \%$ of the total seeds inventoried and presented seed density higher than the eastern transects. On the other hand, the transects sampled in the east and south directions showed lower abundance and average seed density (table 1). We found no significant relationships between the tree crown radius in the N, S, E, W directions and the number of seeds inventoried in each of them $(r=-0.2901, p=2671)$.

Table 1: Number of seeds and seedlings of Swietenia macrophylla and mean density per transect in the municipality of Palestina do Pará, Pará. Equal letters indicate absence of significant difference (Tukey's HSD test, $\mathrm{p}<0.05)$.

\begin{tabular}{|c|c|c|c|c|c|c|}
\hline \multicolumn{2}{|c|}{ Direction } & $\mathrm{N}$ & Abundance (\%) & Mean density $\left(\mathrm{m}^{-2}\right)$ & $\underline{\underline{1}}$ Standard Deviation (m) & C.V. (\%) \\
\hline \multirow{2}{*}{$\mathrm{N}$} & Seeds & 106 & 30.65 & $0.265 \mathrm{a}$ & 0.59 & 22.23 \\
\cline { 2 - 8 } & Seedlings & 14 & 26.41 & $0.035 \mathrm{ab}$ & 0.10 & 24.91 \\
\hline \multirow{2}{*}{$\mathrm{S}$} & Seeds & 35 & 10.1 & $0.09 \mathrm{ab}$ & 0.14 & 67.39 \\
\cline { 2 - 8 } & Seedlings & 12 & 22.64 & $0.03 \mathrm{ab}$ & 0.055 & 46.3 \\
\hline \multirow{2}{*}{$\mathrm{E}$} & Seeds & 5 & 1.45 & $0.012 \mathrm{~b}$ & 0.05 & 43.8 \\
\cline { 2 - 8 } & Seedlings & 4 & 7.55 & $0.01 \mathrm{ab}$ & 0.91 & 49.24 \\
\hline \multirow{2}{*}{$\mathrm{W}$} & Seeds & 200 & 57.8 & $0.5 \mathrm{c}$ & 0.13 & 2.17 \\
\cline { 2 - 8 } & Seedlings & 23 & 43.40 & $0.06 \mathrm{~b}$ & 0.64 & 23 \\
\hline \multirow{2}{*}{ Total } & Seeds & 346 & 100 & 0.033 & 0.11 & 29.73 \\
\cline { 2 - 8 } & Seedlings & 53 & 100 & & & 32.93 \\
\hline
\end{tabular}

Most of the seedlings were inventoried in the western (43.40\%) and northern (26.40\%) transects. The abundance of seedlings was lower in the south (22.65\%) and east (7.55\%) transects. We found significant 
differences in mean density of seedlings $/ \mathrm{m}^{2}$ between transects $\left(F_{(3.396)}=3.253, p<0.05\right)$. Seedling density was higher in the western transect $\left(0.06\right.$ ind $\left.\mathrm{m}^{-2}\right)$ in comparison to the eastern transect $(0.01 \mathrm{ind} \mathrm{m}-2)$, as expected, since about $60 \%$ of the seeds were also found in the west transect and the minority in the east (1.45\%) (table 1).

\section{Parental distance of seeds and seedlings}

Seeds and seedlings of S. macrophylla were found at a mean distance of $22.02 \pm 13.01 \mathrm{~m}$ and $21.96 \pm$ $13.3 \mathrm{~m}$, respectively, with total range of $48 \mathrm{~m}(\min 2 \mathrm{~m}$, $\max 50 \mathrm{~m})$ (table 2$)$. The distance class, in relation to the matrix, with the greatest number of seeds and seedlings inventoried was 10 to $20 \mathrm{~m}$, with 92 seeds and 17 seedlings, corresponding to $26.58 \%$ and $32.08 \%$ of the total, respectively. About $70 \%$ of seeds and seedlings were located up to $30 \mathrm{~m}$ away from the parent trees (figure 2).

We found significant differences in the mean dispersal distance of the seeds in relation to the matrices, between the transects $\left(F_{(3.342)}=41.891, p<0.001\right)$. The inventoried seeds in the west direction presented the largest average dispersal distance of $26.33 \mathrm{~m}( \pm 12.77)$ when compared to the other transects. The west and north directions showed the highest range of seed dispersal $(46 \mathrm{~m}$ and $40 \mathrm{~m})$. In the north direction the seeds were dispersed at a distance $(20.28 \pm 9.41)$ higher than those in the south $(4.34 \pm 4.61)$.

However, the dispersal distance between the east and south and east and north directions were not significant. Seeds of the south and east transects showed the lowest means of seed dispersal distance in relation to the matrices, with $4.34 \mathrm{~m}(\mathrm{SD} \pm 4.61)$ and $10 \mathrm{~m}(\mathrm{SD} \pm 7.62)$, and small ranges of $18 \mathrm{~m}$ and $16 \mathrm{~m}$, respectively, being closer to the parent trees (table 2 ). In the western transect, half of the seeds (50\%) that were inventoried were more than $26 \mathrm{~m}$ away from the mother tree, while in the eastern transect, most of the seeds (60\%) were within $8 \mathrm{~m}$ of the parent tree, and the rest $(40 \%)$ at up to $18 \mathrm{~m}$.

Table 2: Parameters of dispersal distance of seeds and seedlings per transect located in different directions of the matrices. Equal letters indicate absence of significant difference (Tukey HSD test, $p<0,05$ ).

\begin{tabular}{|c|c|c|c|c|}
\hline $\begin{array}{c}\text { Direct } \\
\text { ion }\end{array}$ & $\begin{array}{c}\text { Range of dispersal distance } \\
\text { of seeds }(\mathrm{m})\end{array}$ & $\begin{array}{c}\text { Range of dispersal distance } \\
\text { of seedlings }(\mathrm{m})\end{array}$ & $\begin{array}{c}\text { Mean dispersal distance } \\
\text { of seeds }(\mathrm{m})\end{array}$ & $\begin{array}{c}\text { Mean dispersal distance of } \\
\text { seedlings (DP) }\end{array}$ \\
\hline North & $2-42$ & $6-50$ & $20.28 \pm 9.41 \mathrm{a}$ & $24.86 \pm 14.03 \mathrm{a}$ \\
\hline South & $2-20$ & $2-32$ & $4.34 \pm 4.61 \mathrm{~b}$ & $17 \pm 9.93 \mathrm{a}$ \\
\hline East & $2-18$ & $10-28$ & $10 \pm 7.62 \mathrm{ab}$ & $16.5 \pm 8.54 \mathrm{a}$ \\
\hline West & $4-50$ & $2-50$ & $26.33 \pm 12.77 \mathrm{c}$ & $23.74 \pm 14.65 \mathrm{a}$ \\
\hline Total & $2-50$ & $2-50$ & $22.02 \pm 13.01$ & $21.96 \pm 13.3$ \\
\hline
\end{tabular}

Regarding the seedlings, we found no significant differences in the average distance of transects in relation to the matrices $\left(F_{(3.49)}=1.151, p>0.05\right)$. However, in the western direction the seedlings presented the greatest distance range in relation to the matrices $(2-50 \mathrm{~m})$ when compared to the others. Already in the east direction the seedlings showed the smallest distance range in relation to the matrices $(10-28 \mathrm{~m})($ table 2).

When plotting the cumulative number of seeds and seedlings as a function of the dispersal distance, we observed that the cumulative curves tend to stabilize within the $50 \mathrm{~m}$ radius of the matrices in the south and east directions and continue to rise in the north and mainly west directions. In the south and east 
transects the cumulative number of seeds stabilizes around 18 and $20 \mathrm{~m}$ distance from the matrices, respectively, and in the north transect, around $42 \mathrm{~m}$. In the west direction, the curve continues to rise, with a slope in $50 \mathrm{~m}$ distance from the matrix trees, i.e., by increasing the size of this transect, more seeds could occur (figure 3).

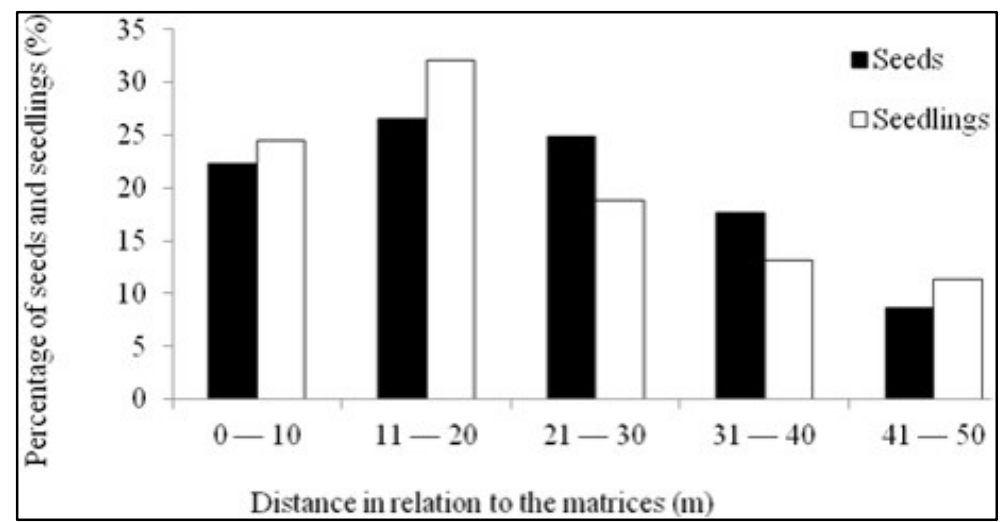

Figure 2: Number of seeds and seedlings sampled according to distance classes in relation to matrices ( $N=346$ seeds and 53 seedlings).

As for the seedlings, the cumulative curves of the emergence of new individuals stabilized from the 28 and $32 \mathrm{~m}$ distance of the matrices in the east and south directions, respectively, but continued ascending to the $50 \mathrm{~m}$ distance in the north and west directions, suggesting that more individuals could be inventoried in these directions with an increase of the transects size (figure 4).

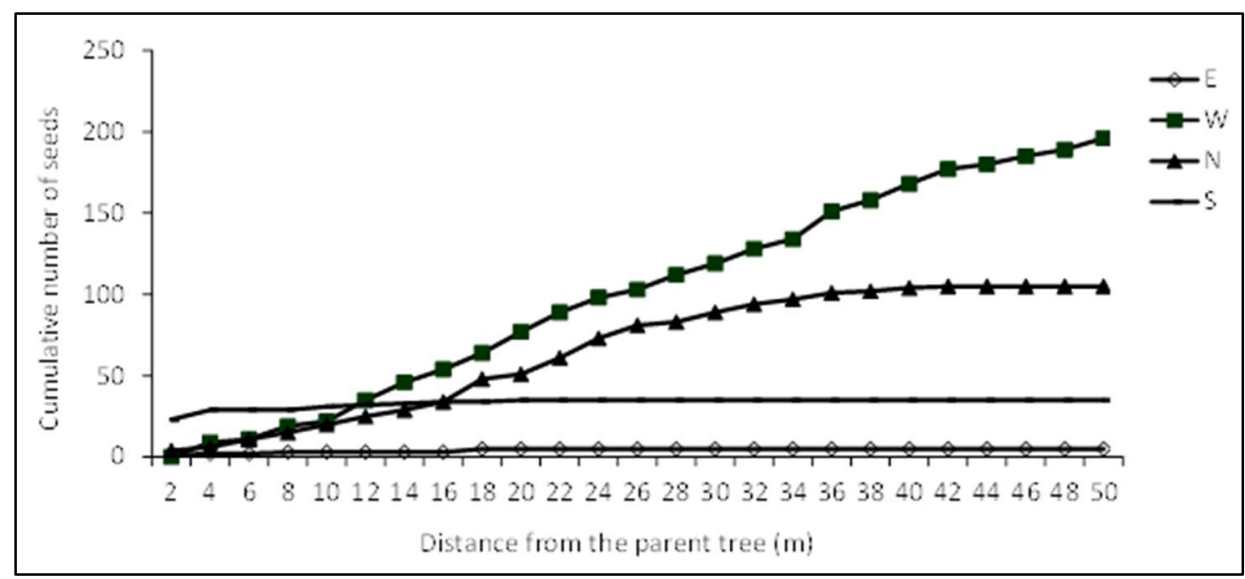

Figure 3: Cumulative number of seeds of Swietenia macrophylla in the directions N, S, E, W, in relation to the distance of the matrix trees.

We found no significant differences in the mean dispersal distance of the seeds, according to their state: intact, predated and aborted $\left(\mathrm{F}_{(2.345)}=4.624, \mathrm{p}<0.05\right)$ (table 3$)$. The intact seeds reached an average distance of $23.30 \pm 13.1 \mathrm{~m}$ from the mother tree, being significantly greater than the average distance found for the aborted ones, of $19.67 \pm 12.43 \mathrm{~m}(\mathrm{p}<0.05)$. We also found no significant difference between the mean dispersal distance of the intact and predated seeds $(p>0.05)$ and between the aborted and predated seeds ( $p>0.05$ ), mainly due to the high coefficient of variation and low number of predated seeds sampled, although the intact and aborted seeds had higher range of seed dispersion $(2-50 \mathrm{~m})$ than predated seeds ( 2 $-36 m)$. 


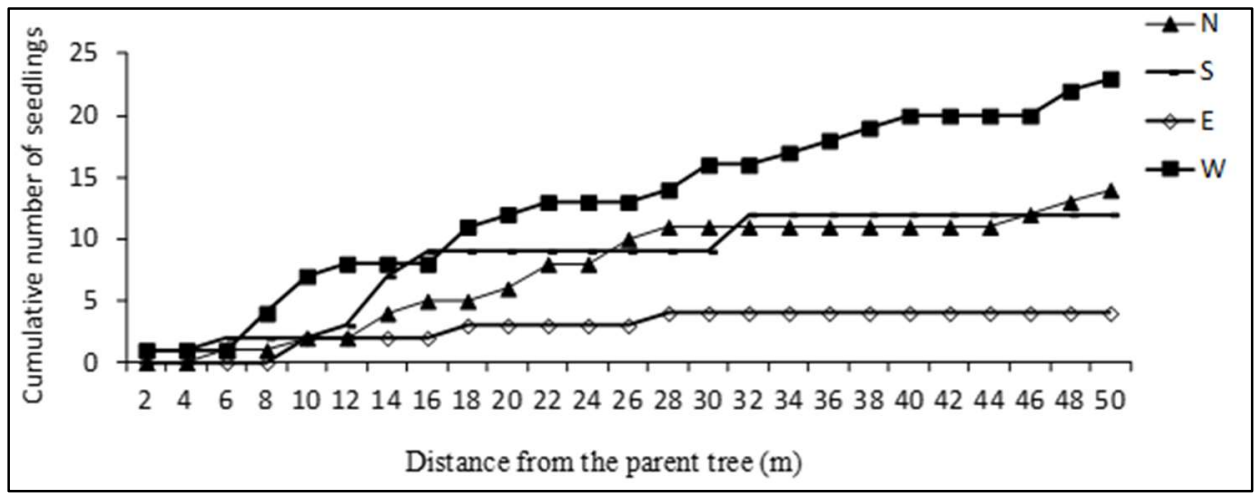

Figure 4: Cumulative number of seedlings of Swietenia macrophylla in the directions N, S, E, W, in relation to the distance of the matrix trees.

Table 3: Parameters of dispersal distance of seeds found in different survival states $(\mathrm{N}=346)$. Equal letters indicate absence of significant difference (Tukey HSD test, $p<0,05$ ).

\begin{tabular}{|l|c|c|c|}
\hline \multirow{2}{*}{ Dispersal distance } & \multicolumn{3}{c|}{ State of seeds } \\
\cline { 2 - 4 } & Intact $(\mathrm{n}=238)$ & Aborted $(\mathrm{n}=90)$ & Predated $(\mathrm{n}=18)$ \\
\hline Mean $(\mathrm{m})$ & $23.31 \mathrm{a}$ & $19.67 \mathrm{~b}$ & $16.66 \mathrm{ab}$ \\
\hline \pm Standard Deviation $(\mathrm{m})$ & 13.10 & 12.43 & 2.25 \\
\hline Range $(\mathrm{m})$ & $2-50$ & $2-50$ & $2-36$ \\
\hline Coefficient of Variation $(\%)$ & 56.20 & 63.20 & 73.70 \\
\hline
\end{tabular}

\section{Predation, seed morphometry and seedling size}

Of the 346 seeds sampled, $69 \%$ were intact or viable $(n=238), 26 \%$ were aborted $(n=90), 4.5 \%$ were predated by insects $(n=16)$ and less than $1 \%$ were predated by rodents $(n=1)$ and infested with fungi ( $n=$ 1). The peeled seeds (without exosperm) measured $(n=65)$ had an average length of $2.03 \mathrm{~cm}$ and an average width of $1.04 \mathrm{~cm}$. We found no strong heterogeneity of the variances analyzed (standard deviation and coefficient of variation) for the means of length and width. However, the average width was more conservative, with a lower coefficient of variation, than the average seed length (table 4), which suggests that this last variable is more important in determining the weight. The mean weight of the seeds analyzed with the exosperm removed $(\mathrm{N}=32$ ) was $0.46 \mathrm{~g}$ with $\mathrm{C} . \mathrm{V}=12.3$ (table 4$)$.

Table 4: Weighing $(n=32)$ and morphometry $(n=65)$ of Swietenia macrophylla seeds $(N=4$ trees).

\begin{tabular}{|l|c|c|c|}
\hline \multicolumn{2}{|c|}{ Length $(\mathrm{cm})$} & Width $(\mathrm{cm})$ & Weight $(\mathrm{g})$ \\
\hline Mean & 2.03 & 1.04 & 0.46 \\
\hline$\underline{\underline{ \pm} \text { Standard Deviation }}$ & 0.25 & 0.10 & 0.06 \\
\hline Range & $1.45-2.61$ & $0.8-1.27$ & $0.33-0.57$ \\
\hline Coefficient of Variation (\%) & 12.10 & 9.40 & 12.30 \\
\hline
\end{tabular}

Table 5: Average height of seedlings from four matrices of Swietenia macrophylla, in the municipality of Palestina do Pará, Pará. Equal letters indicate absence of significant difference (Tukey HSD test, $\mathrm{p}<0.05$ ).

\begin{tabular}{|c|c|c|c|c|c|c|c|}
\hline \multirow[b]{2}{*}{ Height $(\mathrm{cm})$} & \multicolumn{4}{|c|}{ Directions } & \multicolumn{2}{|l|}{ Environment } & \multirow{2}{*}{$\begin{array}{l}\text { Total } \\
(N=53)\end{array}$} \\
\hline & $\begin{array}{l}\text { North } \\
(n=14)\end{array}$ & $\begin{array}{l}\text { South } \\
(n=12)\end{array}$ & $\begin{array}{c}\text { East } \\
(n=4)\end{array}$ & $\begin{array}{c}\text { West } \\
(n=23)\end{array}$ & $\begin{array}{l}\text { Understory } \\
(n=43)\end{array}$ & $\begin{array}{l}\text { Clearing } \\
(n=10)\end{array}$ & \\
\hline Mean & $32.21 a$ & $32.5 a$ & $33.75 a$ & $30.78 a$ & $29.67 a$ & $40.80 \mathrm{~b}$ & 31.8 \\
\hline Standard Deviation & 11.17 & 6.75 & 11.06 & 9.67 & 7.08 & 12.83 & 9.40 \\
\hline Range & $21-62$ & $22-45$ & $20-47$ & $15-57$ & $15-47$ & $26-62$ & $15-62$ \\
\hline Coefficient of Variation (\%) & 34.70 & 20.80 & 32.80 & 31.40 & 23.90 & 31.40 & 29.6 \\
\hline
\end{tabular}

The average height of the seedlings was $31.8 \mathrm{~cm}( \pm 9.40)$ (table 5$)$. We found no variation in the mean height of the seedlings between transects $\left(F_{(3.49)}=0.17, p>0.05\right)$ and in the parental distance in relation to the matrix trees $\left(F_{(20,32)}=0.63, p>0.05\right)$. On the other hand, Mahogany seedlings located in a clearing 
environment, in spite of the lower abundance, presented on average, higher height than those located in the understory forest $(t=2.65, p<0.05)$ (table 5$)$.

\section{Density of seeds and seedlings}

The mean seed density increased from east to west directions of the matrices, indicating the $\mathrm{N}-\mathrm{W}$ directions as having the highest number of seeds dispersed (88.45\%). This indicates that the species does not present a random pattern of seed distribution, but a parabolic pattern of seed distribution in the soil. Grogan (2001) also found a similar pattern of seed distribution in the management area of selective logging of mahogany of the Serraria Marajoara - SEMASA, located in the municipality of Redenção, southern Pará, where 59 to $77 \%$ of the seeds were dispersed up to $50 \mathrm{~m}$ away from the matrices, in the W-NW direction.

Gullison et al. (1996) e Cabrales et al. (2009) show that seeds are dispersed mainly in the direction of the strongest winds. In southeastern Pará, during the dry season, the winds blow with more intensity from east to west (GROGAN et al., 2002). In this case, wind is the main factor that influences spatial distribution patterns of mahogany seeds (GROGAN, 2001). Grogan (2001), different from the results of this study, also found influence of the crown shape, analyzed according to its size and height, in the spatial distribution of mahogany seeds. According to him, some trees with many seed inventories, especially on the eastern side, were correlated with the size of the canopy radius in the E - SE direction and with the height of the tree canopy in relation to the neighbor trees.

Seed density may be an indirect indicator of matrix production, however, according to Grogan et al. (2002) and Cabrales et al. (2009) the rate of fruit production in mahogany is highly idiosyncratic, i.e., not all large trees produce abundant fruit, some of the small trees are among the most fertile individuals, and interannual production varies widely in the same individual as well as among populations. Thus, seed availability rates for dispersal are highly unpredictable for a specific tree (GROGAN, 2001).

Despite the higher seed density in the west direction in comparison to the others, seedling density was higher only in comparison to the east transect and did not differ significantly when compared to the north and south transects. This dichotomy may show low seed predation and mortality in the north and south transects, favored by lower density, and consequent establishment of seedlings, since according to Nascimento et al. (2002), density-dependent mortality seems to be the main source of seedlings control in tropical forests. Studying the predation and establishment of seedlings of Tabebuia serratifolia, Amaral et al. (1992) found a density of $0.031 \mathrm{~m}^{-2}$ seedlings, a result very similar to this study, and suggested a low rate of recruitment and survival in the initial stages of establishment of young individuals of this species. This should also be the standard for S. macrophylla.

Grogan (2001) reports that the density of S. macrophylla seedlings established around a 50-meter radius of matrices with high fruit yield may reach one individual per square meter, but with a short permanence in the environment, especially due to the attack of insects, pathogens, water stress and deposition of tree leaves. 


\section{Parental distance of seeds and seedlings}

In southern Pará, Grogan (2001) also found a smaller mean spatial reach in the east and west directions, with more than $50 \%$ of the seeds inventoried to the west of the matrices dispersed beyond 27.5 m. Cabrales et al. (2009) points out that trees with $\mathrm{DBH}<75 \mathrm{~cm}$ suffer more from the wind effect in the direction and dispersal distance of their seeds than those with larger diameters that have large emergent canopies.

The seed dispersal of the smaller trees tends to follow the pattern of main winds, while the larger ones suffer more turbulence from the winds, resulting in a greater variability in the dispersal direction of the seeds. The results of this study corroborate Cabrales et al. (2009), since with a mean DBH of $69.48 \pm 12.21 \mathrm{~cm}$, they are small matrices whose pattern of seed dispersal followed the direction of main winds. Norghauer et al. (2011) found the greatest distance of seed dispersal by large, high-fecundity S. macrophylla trees.

Grogan et al. (2002) points out the clearings as ideal for the vigorous growth of S. macrophylla juvenile plants. Seeds of S. macrophylla can be dispersed $100 \mathrm{~m}$ away in the western direction of the matrices, indicating the tree with the greatest potential to colonize distant clearings (GROGAN, 2001). Norghauer et al. (2011) found a juvenile abundance peak between 35 and $45 \mathrm{~m}$ distance from the mother tree, in the direction of prevailing winds (north and west). In this study, in addition to the west, the cumulative upward curve of the emergence of seedlings $50 \mathrm{~m}$ away from the parent trees to the north, is also an indicative of potential for the colonization of clearings away from the mother plant.

The results found in the present study suggest that the intact seeds take better advantage of the wind impulsion, resulting in a greater distance of dispersion than the aborted ones, which have atrophied size structures and lower weight. However, when only the intact or viable ones are observed, those with smaller sizes and weights reach greater distances than the longer and heavier ones (GROGAN, 2001).

\section{Predation, seed morphometry and seedling size}

By analyzing seeds of S. macrophylla from their fruits, Grogan (2001) found a lower number of intact seeds than those found in this study (62.4\%) and a higher number for aborted seeds (37.6\%). A total of $10.4 \%$ of the seeds inventoried by Grogan (2001) showed signs of predation. This number was exactly double that observed in the present study, when summing the total number of seeds predated by insect, fungi and rodent (5.2\%).

In the other hands, Cabrales et al. (2009) found results like this study with $75 \%$ of viable seeds, $20 \%$ aborted, $4 \%$ predated and less than $1 \%$ infested by fungi. In intensely exploited forests, rats (Proechimys spp.) are the main predators of mahogany seeds (GROGAN et al., 2002). Yet, in these cases, Norghauer et al. (2006) and Grogan et al. (2006) report that rodent mammals are the main seed dispersal predators. In general, in experimental plots allocated to intensively exploited forests, up to $50 \%$ of the seeds can be damaged by animals, insects and fungi (GROGAN et al., 2002). Norghauer et al. (2006), when testing the Janzen-Connell model, did not find differences between the predation of mahogany seeds and the seeds distance from the matrix tree. 
In the present study, the length of the mahogany seed was more important in determining the weight than the width, whereas Nascimento et al. (2002) found greater width variation in relation to the length when studying the morphometry of the seeds of Dinizia excelsa Ducke (Mimosaceae), a tree also anemochory, in the National Forest of Caxiuanã. Regarding the seeds size found in this study, Grogan (2001), in conducting his research in forests further south in the southeastern region of Pará, found values of similar seed morphometry. Whereas Leão et al. (2003), studying seeds of S. macrophylla in forests further north in the southeastern region of Pará, found larger seeds.

Probably, these results reflect an adaptation of S. macrophylla to the different forest physiognomies found in the southeastern region of Pará, with dense ombrophilous forests occurring further north and open forests (with palm trees and vines further to the central south region) (IBGE, 2012). Although they presented similar sizes, the average seed weight analyzed in the present study was larger and more representative than that observed by Grogan (2001).

The results of the present study corroborate Grogan et al. (2002), reporting that seedlings taller than $50 \mathrm{~cm}$ and small trees of $5 \mathrm{~cm}-10 \mathrm{~cm}$ of DBH are rare in understory environments, and occur mainly in the clearings within the area of seed dispersal. Grogan (2001) reports that germination and establishment rates of mahogany are higher in closed forest than in clearing sites, however, recruitment and growth rates of individuals are higher in locations of high luminosity, disturbance, and seasonality. Mahogany requires a high quantity of light (GROGAN et al., 2005) and the shade environment of the understory makes it difficult for its seedlings to remain.

Baima (2001) reports that the natural regeneration of mahogany is found in the less enlightened places of the forest. However, after two years in this shade environment, young plants manifest rickets, no longer responding to changes in light conditions that may exist (GROGAN, 2001). Gonçalves et al. (2012) concluded that young plants of S. macrophylla exhibit physiological plasticity under high or low irradiance, but when exposed to high irradiance, they optimize the carbon gain resulting in greater growth of the root system and the stem of the individuals.

\section{CONCLUSIONS}

According to the data obtained it is possible to conclude that: Swietenia macrophylla showed in the west - north direction ( $\mathrm{W}-\mathrm{N}$ ) as the highest density and distance of seed dispersal, influenced by strong east winds; There is great potential for colonization of mahogany seedlings in the western direction of the matrices, since these seeds can be dispersed more than 50m apart; Seedling density increases from east to west, following the wind dispersion gradient in these directions, and is generally considered low, indicating a low rate of recruitment and survival in the early stages of establishment of young individuals. Intact seeds reach greater dispersion distances than the aborted ones.

Seed abortion is more frequent than predation, with a relatively abundant availability of intact seeds on the ground; Measurements of length and width showed small variations in comparison to other studies carried out in the southeastern region of Pará, which constitute differences intrinsic to each species 
population. The length is the variable that most influences the weight of $S$. macrophylla seeds. The initial establishment of seedlings occurs in understory environments, which showed the greatest abundance of individuals, but those few located in a clearing environment showed an average height. Thus, seedling establishment has no preference for specific sites, however, recruitment and growth seem to be associated with more disturbed sites, with greater edaphoclimatic variation, such as clearings.

\section{REFERENCES}

ARAGÃO, I. L. G.; ALMEIDA, S. S.. Estrutura ecológica comparada de duas populações de acapu (Vouacapoua americana Aubl., CAESALPINIACEAE) em duas florestas de terra firme da Amazônia Oriental. In: LISBOA, P. L. B.. Caxiuanã. Belém: MPEG, 1997. p.277-290.

CÁMARA-CABRALES, L.; KELTY, M. J.. Seed dispersal of bigleaf mahogany (Swietenia macrophylla) and its role in natural forest management in the Yucatán Peninsula, Mexico. Journal of Tropical Forest Science, v.21, p.235-249, 2009.

FREE, C. M.; LANDIS, R. M.; GROGAN, J.; SCHULZE, M. D.; LENTINI, M.; DÜNISCH, O.. Management implications of long-term tree growth and mortality rates: a modeling study of big-leaf mahogany (Swietenia macrophylla) in the Brazilian Amazon. Forest Ecology and Management, v.330, p.46-54, 2014.

GONÇALVES, J. F.; MOURA, C.; JUSTINO, G.; NINA-JUNIOR, A.. Efeito do ambiente de luz no crescimento de plantas jovens de mogno (Swietenia macrophylla King). Scientia Forestalis/Forest Sciences, v.40, p.337- 344, 2012.

GROGAN, J.. Bigleaf mahogany (Swietenia macrophylla King) in southeast Pará, Brazil: a life history study with management guidelines for sustained production from natural forests. Tese (Doutorado) - Yale University School of Forestry \& Environmental Studies, New Haven, 2001.

GROGAN, J.; BARRETO, P.; VERÍSSIMO, A.. Mogno na Amazônia brasileira: ecologia e perspectivas de manejo. Belém: Imazon, 2002.

GROGAN, J.; GALVÃO, J.. Factors limiting post-logging seedling regeneration by big-leaf mahogany (Swietenia macrophylla) in Southeastern Amazonia, Brazil, and implications for sustainable management. Biotropica, v.38, p.219-228, 2006.

GROGAN, J.; LANDIS, R. M.; ASHTON, M. S. \& Galvão, J. Growth response by big-leaf mahogany (Swietenia macrophylla) advance seedling regeneration to overhead canopy release in southeast Pará, Brazil. Forest Ecology and Management, v.204, p.399-412, 2005.

GROGAN, J.; LANDIS, R. M.; FREE, C. M.; SCHULZE, M.; LENTINI, M.; ASHTON, M. S.. Bigleaf mahogany Swietenia macrophylla population dynamics and implications for sustainable management. Journal of Applied Ecology, v.51, p.664-674, 2014.

GROGAN, J.; LOVELESS, M. D.. Flowering phenology and its implications for management of big-leaf mahogany
Swietenia macrophylla in Brazilian Amazonia. American Journal of Botany, v.100, p.2293-2305, 2013.

GULLISON, R. E.; PANFIL, S. N.; STROUSE, J. J.; HUBBELL, S. P.. Ecology and management of mahogany (Swietenia macrophylla King) in the Chimanes Forest, Beni, Bolivia. Botanical Journal of the Linnean Society, v.122, p.9-34, 1996.

GUTIÉRREZ-GRANADOS, G.; JUÁREZ, V.; ALCALÁ, R. E.. Natural and human disturbances affect natural regeneration of (Swietenia macrophylla): implications for rainforest management. Forest Ecology and Management, v.262, p.161-169, 2011.

IBGE. Instituto Brasileiro de Geografia e Estatística. Manual técnico da vegetação brasileira: sistema fitogeográfico, inventário das formações florestais e campestres, técnicas e manejo de coleções botânicas, procedimentos para mapeamentos. Rio de Janeiro: IBGE, 2012.

JANZEN, D. H.. Ecologia vegetal nos trópicos. São Paulo: EDUSP, 1980.

LAMB, F. B.. Mohogany of Tropical America: its Ecology and Management. Ann Arbor: University of Michigan, 1966.

LEÃO, N. V. M.; MARTINS FILHO, S. E. C.; SILVA, C. E.; SIQUEIRA, V. C.; ALMEIDA, J.. Análises de laboratório em frutos e sementes de mogno (Swietenia macrophylla King), coletados na Terra Indígena Parakanã, no estado do Pará. In: CONGRESSSO NACIONAL DE BOTÂNICA, XLIV. Anais. Belém: 2003.

NASCIMENTO, R. A.; ALMEIDA, S. S.. Distribuição espacial da queda dos frutos, morfometria e predação de sementes de Dinizia excelsa Ducke (Mimosaceae). Belém: MPEG, 2002. NORGHAUER, J. M.; NOCK, C. A.; GROGAN, J.. The Importance of Tree Size and Fecundity for Wind Dispersal of Big-Leaf Mahogany. Plos One, v.6, 2011.

NORGHAUER, J.; MALCOLM, B. J. Z.; FELFILI, J.. An experimental test of density- and distant-dependent recruitment of mahogany (Swietenia macrophylla) in southeastern Amazonia. Oecologia, v.148, p.437-446, 2006.

OKSANEN, J.; BLANCHET, F. G.; KINDT, R.; LEGENDRE, P.; O'HARA, R. B.; SIMPSON, G. L.; SOLYMOS, P.; STEVENS, M. H. H.; WAGNER, H.. Vegan: Community Ecology Package. R package version 2.4-0. Honolulu: HPU, 2016.

RCT. R Core Team. R: A language and environment for statistical computing. Vienna: RCT, 2016. 
RICE, R. E.; GULLISON, R. E.; REID, J. W.. Can sustainable management save tropical forest?. Scientific American, v.276, p.34-39, 1997.

RODAN, B. D.; BLUNDELL, A. G.. Can sustainable mahogany stem from CITES science?. Bioscience, v.53, p.619, 2003.

SNOOK, L. K.. Stand dynamics of mahogany (Swietenia macrophylla King) and associated species after fire and hurricane in the tropical forests of the Yucatan Peninsula, Mexico. Tese (Doutorado) - Yale University School of Forestry \& Environmental Studies, New Haven, 1993.
SNOOK, L. K.; JIMÉNEZ, V. A. S.; MUNDO, M. C.; RIVAS, C. C.; EK, F. J. M.; KANTÚN, P. M.; HERNÁNDEZ, C.; MORALES, A. N.; RUIZ, C. E.. Ordenacón de bosques naturales para la explotación sostenible de la caoba (Swietenia macrophylla): experiencias en bosques comunales de México. Unasylva, v.54, p.68-72, 2003.

UNICEF. Fundo das Nações Unidas para a Infância. Sul e sudeste do Pará: hoje/AMAT. Belém: UNICEF, 1996.

A CBPC - Companhia Brasileira de Produção Científica (CNPJ: 11.221.422/0001-03) detém os direitos materiais desta publicação. Os direitos referem-se à publicação do trabalho em qualquer parte do mundo, incluindo os direitos às renovações, expansões e disseminações da contribuição, bem como outros direitos subsidiários. Todos os trabalhos publicados eletronicamente poderão posteriormente ser publicados em coletâneas impressas sob coordenação da Sustenere Publishing, da Companhia Brasileira de Produção Científica e seus parceiros autorizados. Os (as) autores (as) preservam os direitos autorais, mas não têm permissão para a publicação da contribuição em outro meio, impresso ou digital, em português ou em tradução. 